\title{
欧州及び日本におけるサステナブル建築のデザイン手法とその特性に関する研究 CHARACTERISTICS OF SUSTAINABLE BUILDING AND DESIGN METHOD
IN EUROPEAN COUNTRIES AND JAPAN
}

\author{
渋谷達 郎*，岸本達也** \\ Tatsuro SHIBUYA and Tatsuya KISHIMOTO
}

\begin{abstract}
The purpose of this research is to clarify and systematize characteristics of sustainable design methods and sustainable buildings in European countries and in Japan. 650 samples are collected and 135 samples are analyzed through the multi-variable analysis using quantification method type3. As a result, three main factor axes which characterize design methods are lead. 1. Technology vs. Social axis, 2.Long life span vs. High circulation axis, 3. Economics vs. History and Climate axis. Next, using these factor axis characteristics of sustainable building are analyzed with the samples. Characteristics by regions, by building types and by building scale are clarified.
\end{abstract}

Keywords: Sustainable Building; Sustainable Design; Design Method; Quantification Analysis サステナブル建築 サステナブルデザイン デザイン手法 数量化分析

\section{1. 背景と目的}

1987 年の国連ブルントランド委員会における「我ら共有の未 来」1)を契機とした「サステナブル・ディベロップメント」は、 地球環境保全のキーワードとして広く認知されるようになった。 建築分野においても、国際的には 1993 年 6 月のシカゴ会議にお いて、国際建築家連合 (UIA) 及びアメリ力建築家協会 (AIA) が「持続可能な未来のための相互依存宣言」2)を連名で取りまと めたほか、欧州協力開発機構（OECD）が、1998 年から「サス テナブル建築プロジェクト」3)を 4 力年計画で開始している。日 本においても、日本建築家協会（JIA）による「サステナブル． デザインガイド」(1995) 6)をはじめ、日本建築学会 (AIJ) による 「サステナブル・ビルディング普及のための提言」7)(1999)など、 「持続可能な建築」の実現に向けたさまざまな取り組みが行われ ている。

これら各国の持続可能な建築の実現に向けた政策や提言等の動 向に関する既往研究としては村上・白石(1998) 8)が、建築の持続 可能性(通称サステナブル建築)の枠組について、これまでの各国 の取り組みを包括している。この研究では、サステナブル建築の 実現に向けた方策について論じており、単に建築のみが持続して も生活が持続することにはならないこと。つまり、「建築における
持続可能性(サステナビリティ)」の問題は、材料の耐久性や建築 の而用年数といった建築の物理的な寿命として狭義にとらえるの ではなく、社会的な寿命や地球環境の問題として広義にとらえる 必要があることを指摘している。

建築を「サステナブル」なものにしている方法・技術は、(1)材 料の耐久性向上や建築耐用年数の増大といった建築材料に関する もの、(2) $\mathrm{CO}_{2}$ 排出抑制や環境負荷の低減といった建築生産・ライ フサイクルに関わるもの、(3)歴史的建造物の再生やコンバージョ ンといった建筑のリューズ・リデュース・リサイクルに関わるも のなど、多岐にわたる。本研究では、建築を「サステナブル」な ものにしているデザイン上の方法・技術を総称して「サステナブ ル・デザイン手法(以下 SD 手法)」と呼び、こうした手法を取り 込むことによって計画された建築を「サステナブル建築」と呼ぶ ことにする。

先の ЛA「サステナブル・デザインガイド」では、さまざまな 方法・技術の中から、32 項目の SD 手法が分類されている。一般 に、地域ごとに異なる特色を持つことや、多様化・複合化する傾 向にあると思われる。しかし、それらがどのように組み合わされ て「サステナブル建築」となっているかは明らかではない。害際 の建築にあって、SD 手法の組み合わせ方は建築家の経験による
* パシフイックコンサルタンツ(侏) 修士 (工学)

** 慶應義塾大学理工学部システムデザイン工学科 専任講師・博士 (工学)
PACIFIC CONSULTANS CO., LTD., M. Eng.

Assistant Prof., Department of System Design Engineering, Faculty of Science and Technology, Keio University, Dr. Eng. 
ところが多く、それを整理・体系化したものはない。また、SD 手法相互の関連がサステナブル建築の特性を決定すると考えられ るが、その関連は明らかにされていない。そこで本研究では、サ ステナブル建築として論じられている事例を収集して、そこで用 いられている SD 手法を分析・分類し、その特性を明らかにする ことを目的とする。

本論の流れを説明すると、2、では、関連する論文・書籍から サステナブル建築の事例を収集し、SD 手法の分類を行う。 3 . では、収集した事例とそこに用いられているS D 手法の多変量ブ 一夕から数量化 3 類によるS D 手法の分析を行う。その結果導き 出される項目別負荷量を用いてそれぞれグラフ化し、散布図上で S D 手法およびサステナブル建築事例の傾向分析と体系化を行う。 4.では、用途・規模・地域別にそれぞれサステナブル建築の特 性を 3 .で抽出した軸空間上に示し、用途・規模・地域ごとにサ ステナブル建築のデザイン特性を分析し、その特性を明らかにす る。最後の 5 , では本論の成果を総括し、今後の課題について述 ベる。

\section{2. 事例収集と SD 手法の分類}

\section{2-1. 事例の選定}

まず「サスデナブル建築(Sustainable Building)」というキーワ ードで、「Google (http://www.google.com/)」などのインターネッ トを利用したロボット検索を行い、「サステナブル建築」に関する 論文・書籍を収集した。次に、国立国会図書館の「Opac（オンラ イン閲覧目録)」や国立情報学研究所の「NACSIS Webcat (http://webcat.nii.ac.jp/)」、インターネット書店の「Amazon (http://www.amazon.com/)」などを活用し、サステナブル建築の 論文・書籍を特定し、そこから掲載されているサステナブル建築 の事例を収集した。

収集した文献は、文末に揭載した 9）から 60）までの国内外の 雑誌 10 種 23 誌、専門書 29 冊である。多くの事例を収集した主 な文献を挙げると以下の 3 つである。「日経アーキテクチュア」18) 一28)は、日経 BP 社発行の建築総合情報誌である。購読は契約制で あるが、現在約 5 万人が購読している。日本国内だけでなく、海 外建築の動向にも詳しく、「環境デザイン」や「エコデザイン」に 関する特集も多い。この中から約 50 事例を収集した。

「Sustainable architecture」14)はオランダ建築家協会発行のサス テナブル建築の事例集である。主にオランダと欧州の建築事例に ついて取り上げられている。実現したサステナブル建築の事例の 他に、プロジェクト案も数多く取り上げられている。この中から 36 事例を収集した。「Sustainable architecture and urbanism」 30)は持続可能な建築及び都市プロジェクトに関する事例集である。 集合住宅、公共建築、商業・業務建築の3つに分類され、体系化

表 1 収集事例の国別集計

\begin{tabular}{|c|c|c|c|c|c|c|c|c|c|c|c|c|c|c|c|c|}
\hline & $\begin{array}{l}1 \\
\neq \\
1 \\
x\end{array}$ & $\begin{array}{l}F \\
1 \\
y\end{array}$ & $\begin{array}{l}\text { オ } \\
\text { ラ } \\
\text { 年 }\end{array}$ & $\begin{array}{l}7 \\
5 \\
2 \\
2\end{array}$ & $\begin{array}{l}x \\
1 \\
\pi\end{array}$ & $\begin{array}{c}x \\
1 \\
x \\
1 \\
j \\
P\end{array}$ & $\begin{array}{l}1 \\
\text { タ } \\
\text { リ } \\
P\end{array}$ & $\begin{array}{l}x \\
0 \\
1 \\
1 \\
2\end{array}$ & $\begin{array}{l}キ \\
リ \\
シ \\
\text { ア }\end{array}$ & $\begin{array}{l}セ \\
ヒ \\
\text { J } \\
ア\end{array}$ & $\begin{array}{c}P \\
1 \\
\mu \\
3 \\
2 \\
\qquad \\
ト\end{array}$ & $\mid \begin{array}{l}\square \\
\text { 足 } \\
\mathcal{P}\end{array}$ & $\begin{array}{l}7 \\
1 \\
2 \\
5 \\
2 \\
1\end{array}$ & $\begin{array}{l}J \\
ル \\
ウ \\
x \\
1\end{array}$ & $\begin{array}{l}\text { 日 } \\
\text { 本 }\end{array}$ & $\begin{array}{l}\text { 合 } \\
\text { 尌 }\end{array}$ \\
\hline サンプル数 & 27 & 29 & 11 & 13 & 3 & 9 & 5 & 3 & 3 & 1 & 1 & 2 & 1 & 1 & 26 & 135 \\
\hline
\end{tabular}

表 2 抽出した 135 件の事例リスト

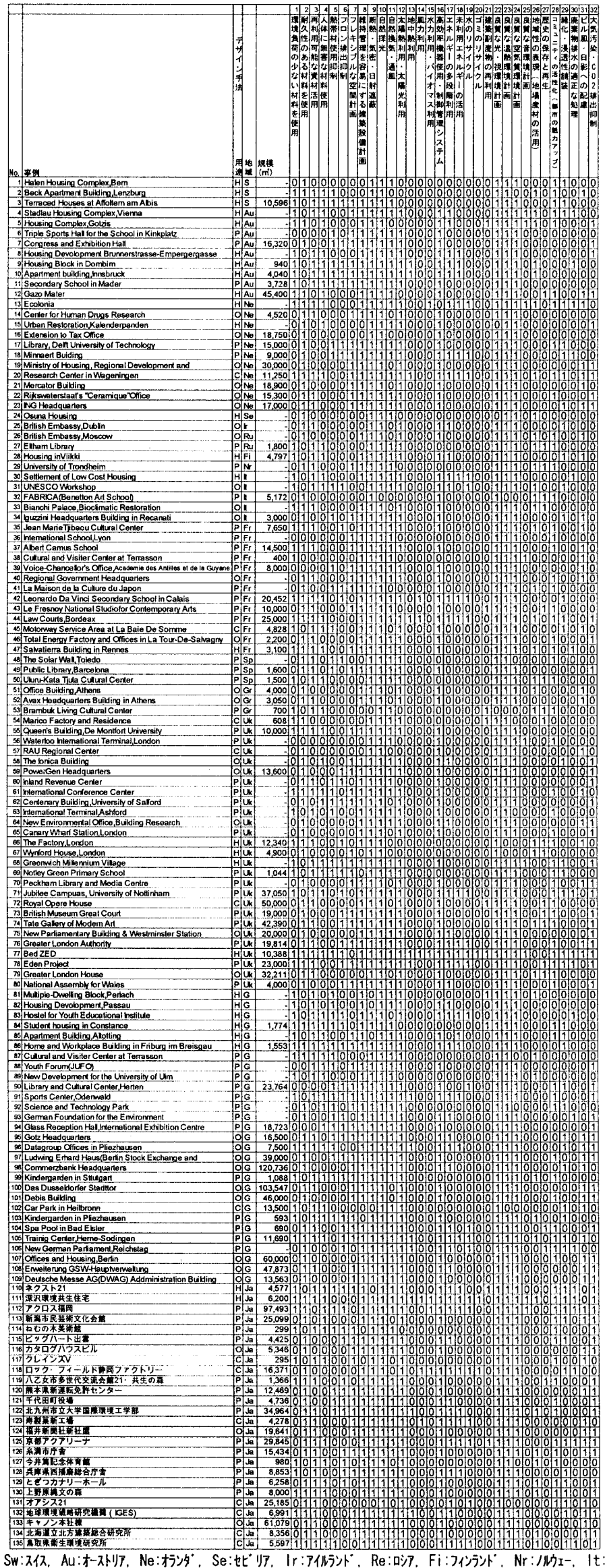

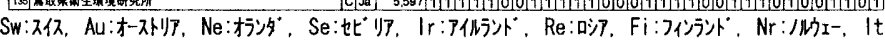

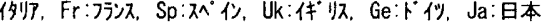

$H$ : 菜合住宅， 0 :事務所，C:商業施設，P:公共施設 


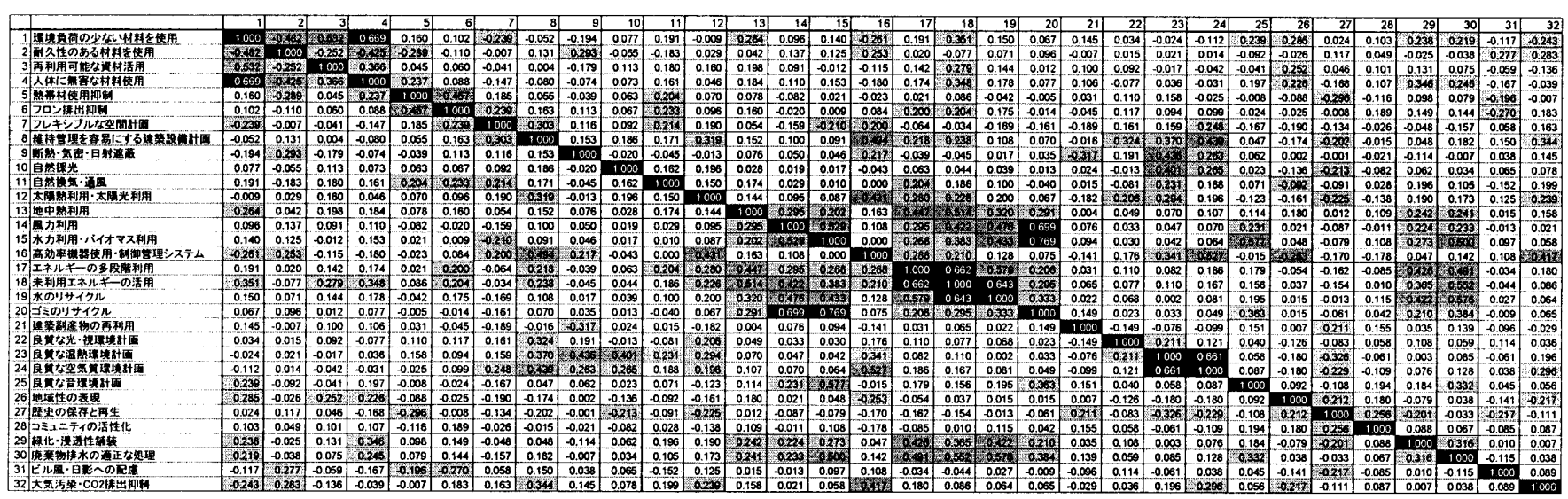

されている。建築写真の他に、建築材料、建設コスト、断面詳細 図などの設計に関わる詳細情報が掲載されている。この中から 22 事例を収集した。

事例収集の結果、延べ 650 事例が収集された。650 事例の内訳 は、欧州諸国及び日本の 1980 's 以降の現代建築が大半を占める結 果となった。このため、今回の分析対象を欧州及び日本の事例に ついて行うこととし、事例の少なかったアジア諸国や米国は今後 の研究課題として分析詨象から除外することとした。また収集し た中から、(1)独立戸建て住宅、(2)博覧会やイベント等の仮設建築 物、(3)橋梁・河川などの土木構造物、(4)プロジェクト・コンペ案 など実際には建設されていないもの、(5)図面・構造・規模など、 分析に必要な情報が不明のものを除外し、分析対象を 135 事例に 絞込んだ。国別の内訳は表 1 の通りである。イギリス 27 事例、 ドイツ 29 事例、オランダ 11 事例、フランス 13 事例、スイス 3 事例、オーストリア 9 事例、イタリア 5 事例、スペイン・ギリシ ア各 3 事例、ロシア 2 事例、セビリア・アイルランド・フィンラ ンド・ノルウェー各 1 事例、日本 26 事例、合計 135 事例を分析 対象として抽出した。

\section{2-2. $\mathrm{SD}$ 手法の分類}

SD手法の分類は、既往の分類例として ЛA 作成の「サステナ ブル・デザインガイド」 ${ }^{6)}$ を参考にして、これを発展させる方向 で検討した。

まず、「サステナブル・デザインガイド」で分類された 32 項目 について再検討を行うこととした。32 項目についてのチェックシ 一トを作成し、抽出された 135 の事例について、該当する SD 手 法が適用されていれば「1」、適用されていなければ「0」を入力 してデータの数量化を行った。その結果を表 2 に示す。個々の 0 、 1 の判断は、収集したサステナブル建築の論文・書籍の情報から 総合的に判断することにより行った。例えば、「環境負荷の少ない 材料を使用」、「ゴミのリサイクル」など、SD 手法が具体的な手 法・技術の場合には、その手法や技術が用いられている場合には 1を入力し、そうでない場合は0を入力した。「地域性の表現」、 「コミュニティの活性化など、内容が抽象的な項目については、 判断が難しいため、抽出した 135 事例から、より的確に当てはま る名称を検討し、項目名に変更した。例えば、サステナブル・デ ザインガイドにおける「地域性の表現」という SD 手法は、135
事例の中で複数の事例で用いられていた「地場産材の活用」に変 更し、地場産材が主な材料として掲げられていれば 1 を、そうで ない場合には 0 を入力した。「コミュニティの活性化」は、より 意味の広い「都南の魅力アップ」に変更している。これは、来訪 者が増加し、地域の活性化につながるなど、建築が建ったことで 都市の魅力が向上したことが文献等に記載されていれば 1 を、そ うでない場合には 0 を入力した。「大気污染・ $\mathrm{CO}_{2}$ 排出抑制」に ついては、京都議定書などで地球環境保全に関わる具体的な数值 目標が掲げられており、すべてのサステナブル建築が対象となる 重要な項目のため、特に主要なコンセプトとして掲げられている 事例のみを数量化の対象とした。

次に、作成したテーブルデータをもとに、32 項目の SD 手法 について、相関分析を行った。その結果を表 3 に示す。データの 冗長性を考慮して、相関性が著しく高い複数のSD 手法を集約す る作業を行った。例えば、「地中熱利用小、「風力利用」、「水力利 用・バイオマス利用」、「高効率機器使用・制御管理システム」、「エ ネルギーの多段階利用」、「未利用エネルギーの活用」、「水のリサ イクル、「ゴミのリサイクル」「廃革物排水の適正な処理」は、 相互に高い相関性が見られたため、「未利用エネルギーの利用」と して集約した。また、「緑化・浸透性舗装」は、屋上緑化の事例が 多かったため、屋上緑化」と項目名を変更した。このように、抽

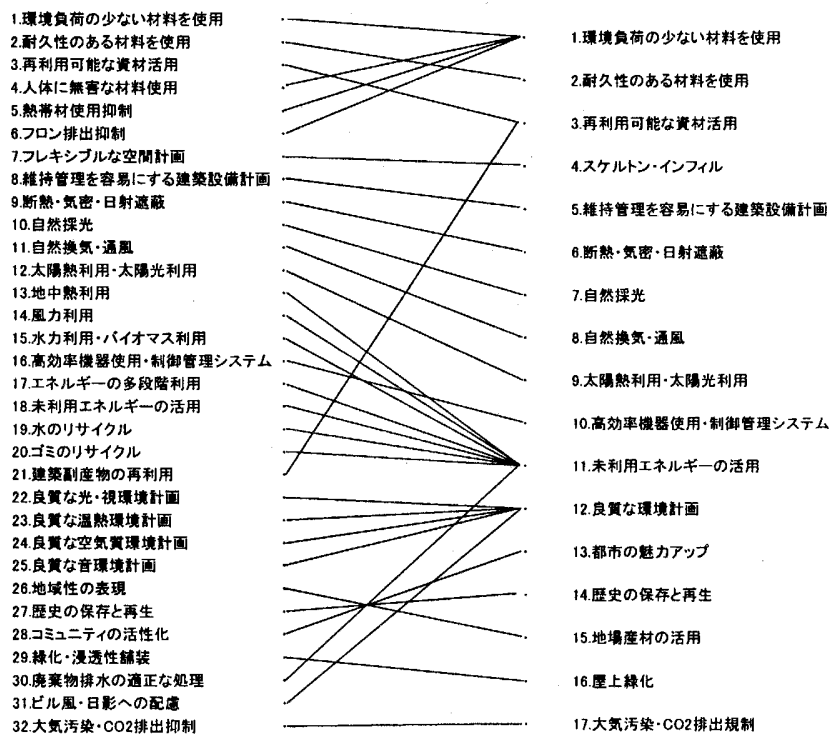

図 132 項目一 17 項目対忘表 
出された 135 事例から相応しい項目名称に変更する操作を行うこ とで、項目名に具体性を持たせた。その結果、32 項目は、図 1 に示すように、17 項目に整理された。

\section{3. 数量化 3 類による多変量解析}

2. で作成された 32 項目の SD 手法のテーブルデータを、図 1 の対応表から 17 項目のテーブルデータへ変換し、それに対して 数量化 3 類による多変量解析を行う。そこから SD 手法の特性を グラフ化して分析することでサステナブル建築の特性を明らかに する。数量化 3 類は、「0」、「1」などであらわされるカテゴリー データを多変量解析する手法であり、主成分分析のように、項目 と事例双方の特徴を分析することができる。

まず、17 項目のSD 手法において、項目別負荷量を表 4のテー ブルデータを用いて分析した。表 4 を見ると、第 1 成分において は固有值が 0.135 、寄与率が $22.36 \%$ であり、第 2 成分においては、 固有值が 0.112 、寄与率が $18.451 \%$ 、第 3 成分では、固有值が 0.063 、 寄与率が $10.448 \%$ となった。第 6 成分までの累積寄与率が $73.87 \%$ であり、固有值、寄与率共に全体的に低い傾向を示した。これは、 相関分析の結果からもわかるように、項目数が 17 項目と多く、 突出して強い傾向を持つSD 手法が比較的少ないためである。

次に、成分ごとの分析結果を用いて、成分 1 、成分 $2 、$ 成分 3 の項目別負荷量をグラフ化した。図 2 を見ると、成分 1 では「歴 史の保存と再生」、「都市の魅力アップ」、「地場産材の活用」、「環 境負荷の少ない材料を使用」などがネガティブに作用しているの に対し、「大気污染・ $\mathrm{CO}_{2}$ 排出抑制」「スケルトン・インフィル」

「高効率機器使用」「維持管理を容易にする設備計画」などがポジ

表 4 数量化 3 類による分析結果(\%)

\begin{tabular}{|c|c|c|c|c|c|c|c|}
\hline & 項目/カテデ゙リ & 成分1 & 成分2 & 成分了 & 成分 4 & 成分 5 & 成分 6 \\
\hline 1 & 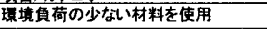 & -1.717 & -1.871 & 1.171 & 1.228 & 0.301 & -0.534 \\
\hline & 付久性のある材料を使用 & 0.4 & 1.118 & -0.668 & -1.46 & -0.162 & 0.766 \\
\hline 3 & 再利用可能な海材活用 & -0.889 & -0.904 & 0.792 & 0.763 & 0.448 & -0.15 \\
\hline 4 & スケルトン・インフィル & 1.039 & 0.555 & 0.913 & 1.542 & -0.47 & 0.565 \\
\hline 5 & 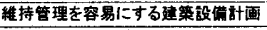 & 0.545 & 0.076 & 0.343 & 0.115 & 0.384 & -0.108 \\
\hline 6 & 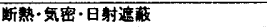 & 0.102 & 0.416 & 0.262 & -0.268 & -0.081 & 0.477 \\
\hline 7 & 自然操光 & 0.019 & 0.146 & 0.313 & -0.047 & -0.095 & 0.416 \\
\hline 8 & 自然換羿-通風 & 0.117 & -0.264 & 0.373 & 0.848 & -0.206 & -0.218 \\
\hline 9 & 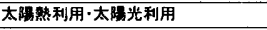 & 0.441 & -0.174 & 0.19 & 0.038 & 0.494 & 0.343 \\
\hline 10 & 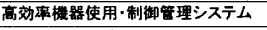 & 0.774 & 0.303 & -0.113 & -0.409 & 0.839 & 0.292 \\
\hline 11 & 末利用エネルキーの活用 & -0.035 & -3.06 & -2.966 & -0.991 & 3.037 & -1.15 \\
\hline 12 & 食賢な㻴填社画 & 0.051 & 0.147 & 0.223 & 0.018 & -0.11 & 0.492 \\
\hline 13 & 都市の趚カアップ & -3.14 & 0.514 & 1.819 & -3.711 & 0.038 & -0.742 \\
\hline 14 & 画史の保存と再生 & -4.374 & 3.822 & -4.289 & 3.091 & 2.226 & 1.587 \\
\hline 15 & 地㙁産材の活用 & -0.906 & 0.451 & -1.066 & 0.434 & -2.746 & -2.008 \\
\hline 16 & 屋上緑化 & 0.325 & -2.523 & -2.253 & -0.753 & -2.53 & 1.93 \\
\hline & 大兵活策·CO2排出抑制 & 1,525 & 0.791 & -0.703 & -0.175 & 0.508 & -3.216 \\
\hline & 固有值 & 0.135 & 0.112 & 0.063 & 0.05 & 0.045 & 0.041 \\
\hline & 奇与赍 & 22.36 & 18.451 & 10.448 & 8.295 & 7.48 & 6.843 \\
\hline & 累皘寄与毦 & 22.36 & 40.811 & 51.258 & 59.553 & 67.034 & 73.877 \\
\hline
\end{tabular}

ティブに作用していることがわかる。成分 2 では、「未利用エネル ギ一の活用」、「屋上緑化」、「環境負荷の少ない材料を使用」、「再 利用可能な資材活用」などがネガティブに作用するのに対し、「歴 史の保存と再生」耐久性のある材料を使用」などがポジティブに 作用している。さらに成分 3 についは、「歴史の保存と再生小、

「未利用エネルギ一の活用」「屋上緑化」「地場産材の活用」が ネガティブに作用し、「都市の魅力アップ」「環境負荷の少ない材 料を利用」「スケルトン・インフィル」などがボジティブに作用し ている。

\section{3-1. 1-2 成分軸を用いた SD 手法の特性分析}

成分 1 と成分 2 の直交軸による空間上に、 17 の SD 手法をプ ロットすると図 3 のようになる。ここから、(1)歴史の保存と再生、 都市の魅力アップ、地場産材の活用といった主に「社会との関わ り」に関するグループ、(2)耐久性のある材料を使用、大気污染・ $\mathrm{CO} 2$ 排出抑制、太陽熱利用・太陽光利用など主に「人と技術」に 関するグループ、(3)環境負荷の少ない材料、未利用エネルギーの 活用、屋上緑化などの「高循環・軽負荷」に関するグループの 3 つに SD 手法をグルーピングし、その特性を明らかにすることが できた。

以上により、それぞれのS D手法の分布から、第 1 成分はサス

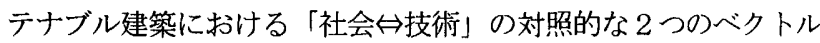
(特徵・方向性)を表すものと考えられる。また第 2 成分は、「高循 環・ライトネス注1) $\Leftrightarrow$ ロングライフスパン・ロバストネス 対照的な 2 つのベクトルを表すものと考えられる。

次に、サステナブル建築の代表的な 8 事例について、図 4 のよ うに 1-2 成分軸上に散布して例示寸る。「ライヒスターク」は、 老朽化した議事堂をコ・ジェネレーションシステムなどの設備技 術を駆使して、現在に再生させた事例であり、歷史の保存と再生 や、高効率機器使用・制御管理システムの採用の面においてサス テナブル建築とされる。「ベッドゼット」、「深沢環境共生住宅」、 「ミレニアムビレッジ」は、共に環境共生型の集合住宅としてサ

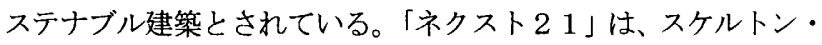
インフィルを採用した集合住宅として、「コメルツバンク」は、高 層建築でありながら、自然換気・通風を実現した建物としてサス テナブル建築とされている。1-2成分軸上においては、高い科学 技術によって SD 手法を高層建築に用いた「コメルツバンク」が 第 1 象限の近くに位置しており、「デートモダン」、「ライヒスタ 一ク」という、公共性の高い事例が共に第 2 象限に位置している。

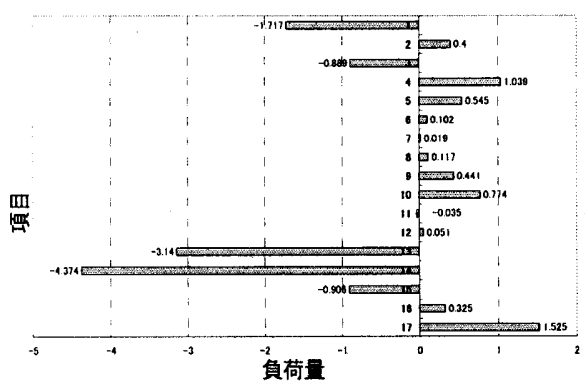

1 軸項目別負荷量（成分 1 ）

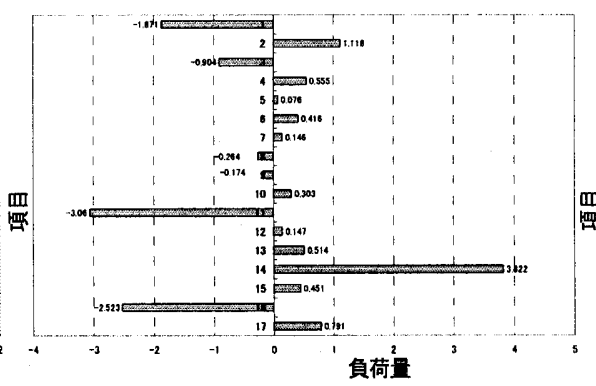

2 軸項目別負荷量（成分 2)

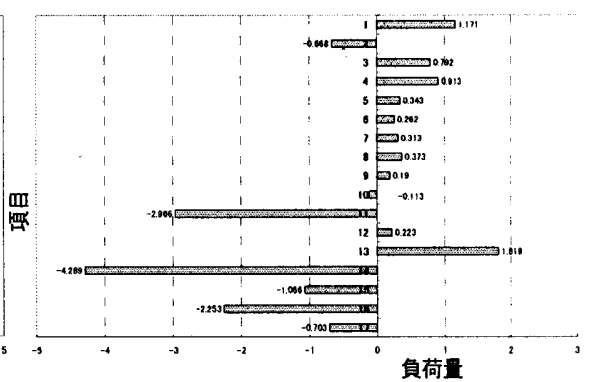

3 軸項目別負荷量（成分 3 )

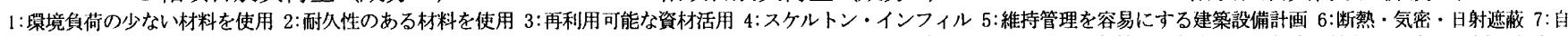

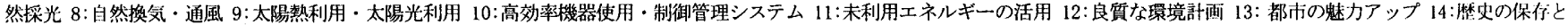
再生: 15: 地場産材の)活用 16 : 屋上緑化 17 : 大気污染・CO2 排出抑制

図 2 項目別負荷量の相対 ( 1 軸, 2 軸, 3 軸) 


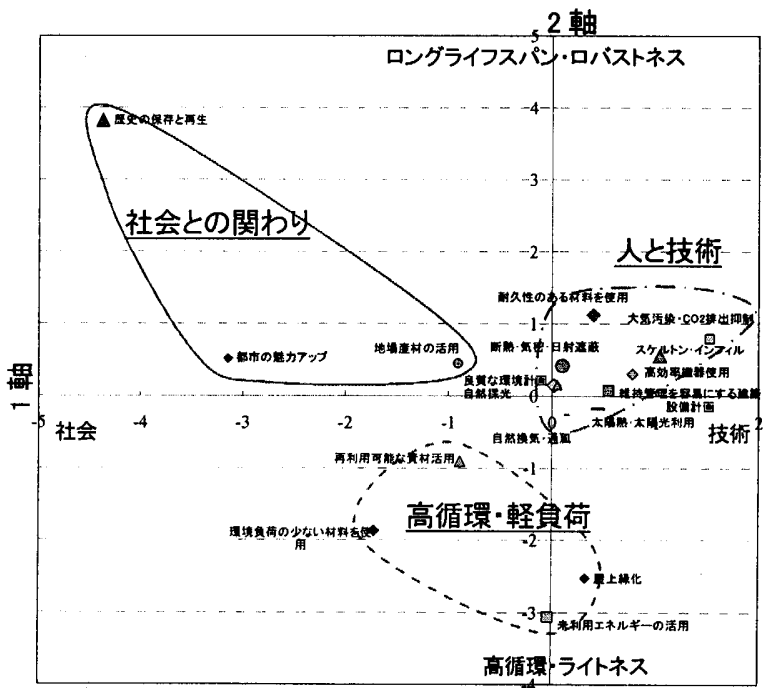

図 3 1.2 軸 2 次元グラフ

2 軸

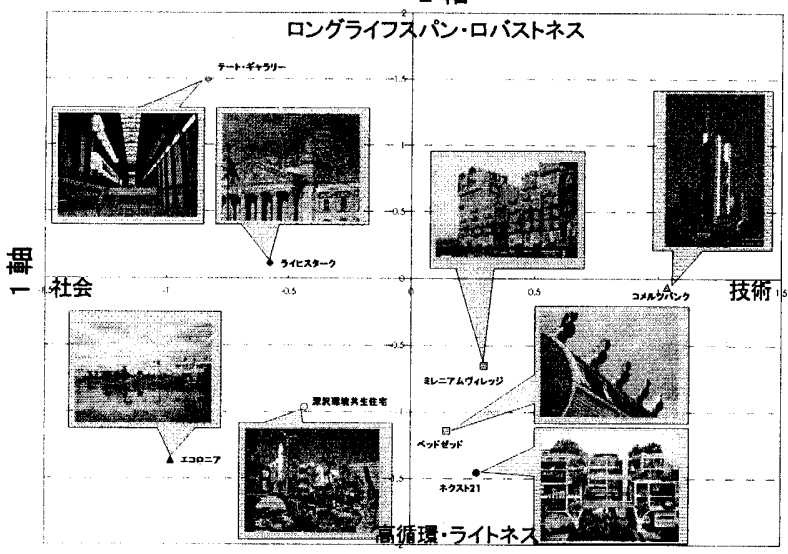

図 4 代表的な 8 事例のプロット図(1-2 軸)

これにより、「社会との関わり」のグループと、「人と技術」のグ ループの特性を確認することができた。一方、スケルトン・イン フィルを採用した「ネクスト $21 」 か ゙$ 第 4 象限に位置し、「高循 環・ライトネス」のグループの特性を確認することができた。

\section{3-2. 1-3 成分軸を用いた SD 手法の特性分析}

同様にして、図 5 に示すように各S D 手法の 1-3 成分軸による 散布図を作成し、その分析を行うとともに、事例による確認を行 った。SD手法の散布図から、(1)歴史の保存と再生や地場産材の 活用、屋上緑化、未利用エネルギーの活用といった「社会・歴史・ 風土」に関するグループ、(2)太陽熱利用・太陽光利用、高効率機 器使用といった「人と技術」に関するグループ、(3)都市の魅力ア ップ、環境負荷の少ない材料を使用、再生可能な資材活用といっ た主に「経済」に関するグループの3つのグループに SD 手法の 特性を明らかにすることができた。この散布図の分布結果から、 第 3 成分は、サステナブル建築における「歷史・風土 $\Leftrightarrow$ 経済」 の対照的な 2 つのベクトルを表すものと考えられ。

代表的な 8 事例を選びそれらを 1-3 成分軸上に散布すると、 図6のような結果となった。第 3 象限に注、社会や歴史・風土と の関わりが強い「深沢環境共生住宅」「「イヒスターク」、「エコ ロニア」が位置しており、第 1 象限及び第 4 象限には、太陽熱や 太陽光を発電・給湯などに積極的に活用した「ミレニアムビレッ

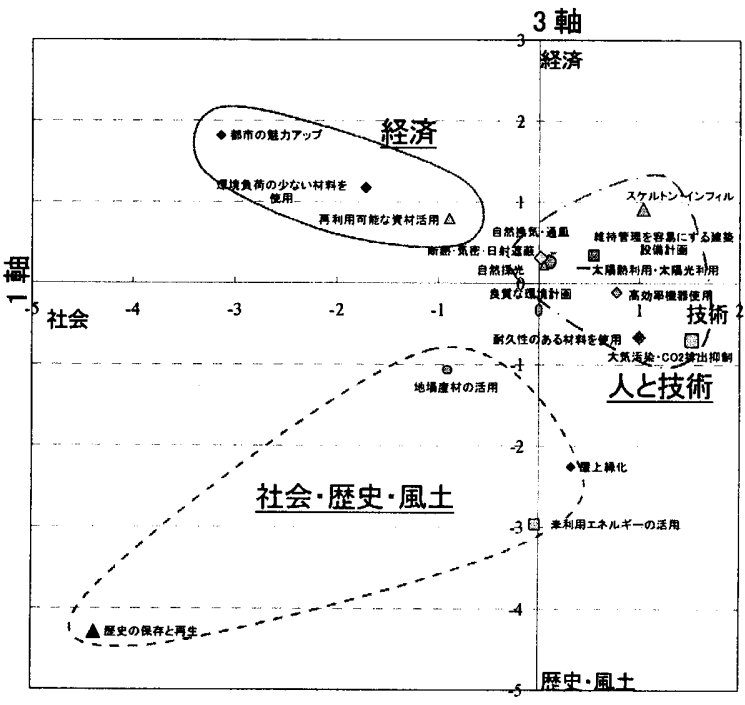

図 $5 \quad 1-3$ 軸 2 次元グラフ

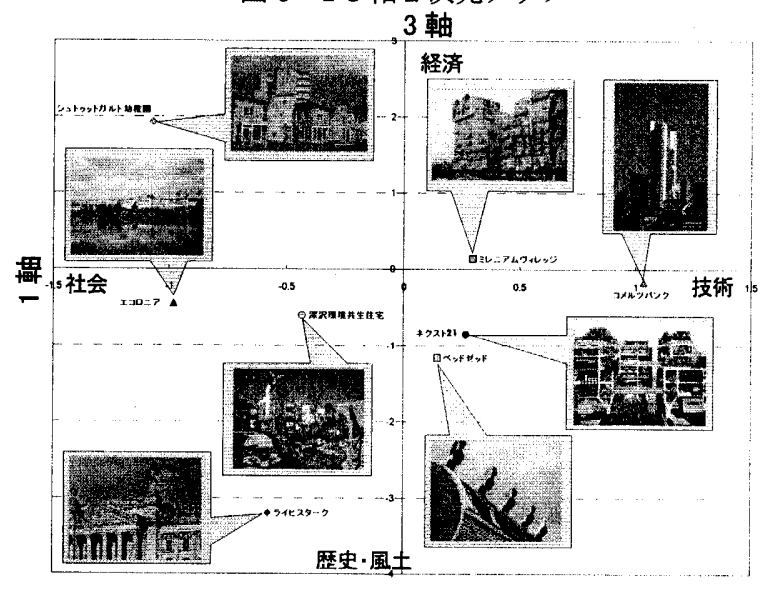

図 6 代表的な 8 事例のプロット図 $(1-3$ 軸)

ジ」の他、スケルトン・インフィルを採用した「ネクスト 21 小、 高層建築である「コメルツバンク」が位置しており、第 2 象限に は、経済性の高いリサイクル材料や環境負荷の少ない材料を建材 として多用した「シュトゥットガルト幼稚園」が位置している。 その結果、それぞれの象限において、「社会・歷史・風土小、「人と 技術」、経済」に関するグループの特性を、それぞれ確認するこ とができた。

\section{4. 用途・規模・地域別サステナブル建築の特徵}

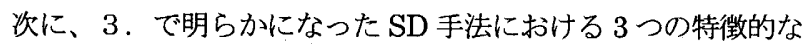
軸性による 6 つのベクトル (「社会 $\Leftrightarrow$ 技術」、「高循環・ライトネス ↔ロングライフスパン・ロバストネス」、「歴史・風土 $\Leftrightarrow$ 経済」) を踏まえ、用途別・規模別・地域別にサステナブル建築の特性を 明らかにする。数量化 3 類の分析結果のうち、寄与率が高かった 成分 1 と成分 2 を用い、135の事例を 1-2 成分軸上にプロット することで、用途・規模・地域別のサステナブル建築の特性を分 析した。

\section{1. 用途別分析}

事例を用途別に散布図として示した結果を図 7 に示す。用途別 にサステナブル建築の特性を分析すると、集合住宅のグループで は、第 2 象限から第 3 象限にかけての分布が多く、比較的社会と の関わりが強く、技術との関わりが低いことが明らかになった。 


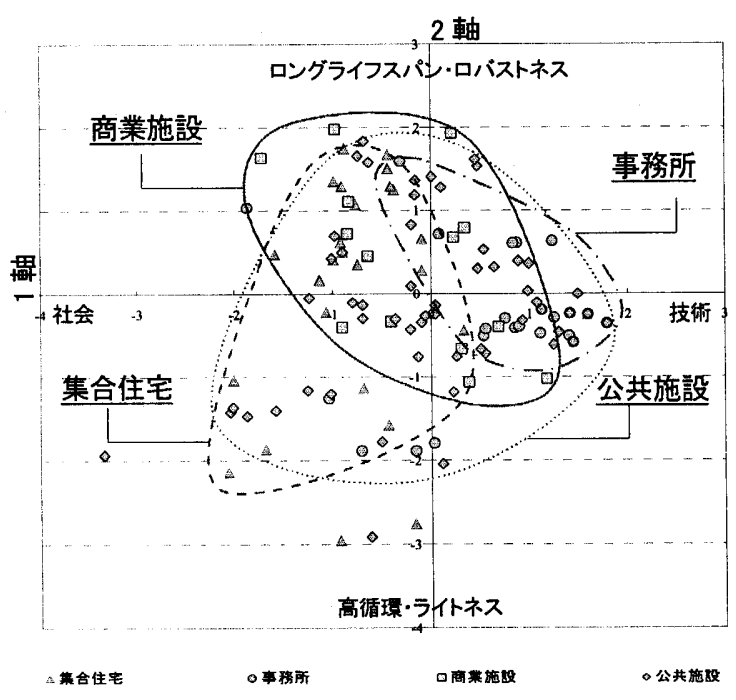

図 $7 \quad 1-2$ 軸 2 次元グラフ(用途別)

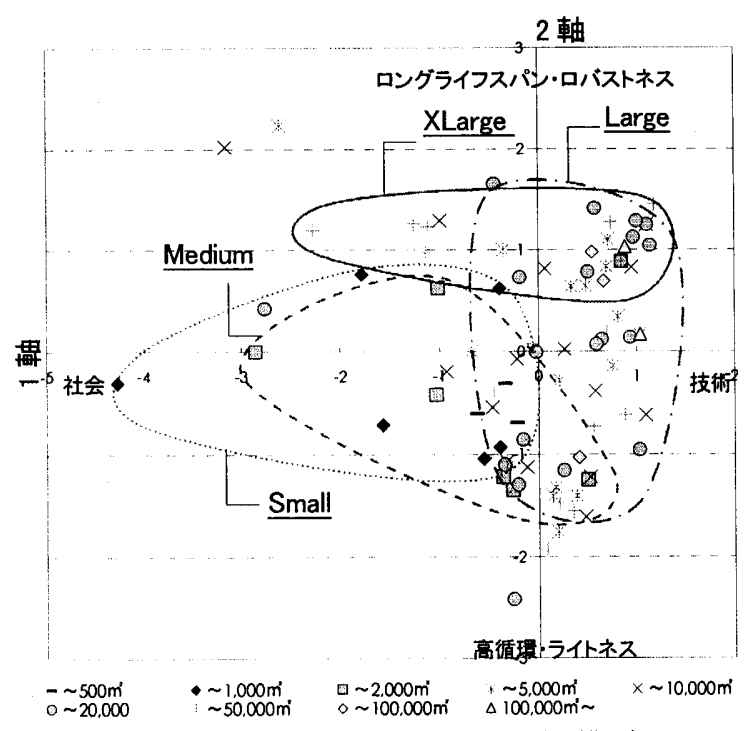

図 $8 \quad 1-2$ 軸 2 次元グラフ（規模別）

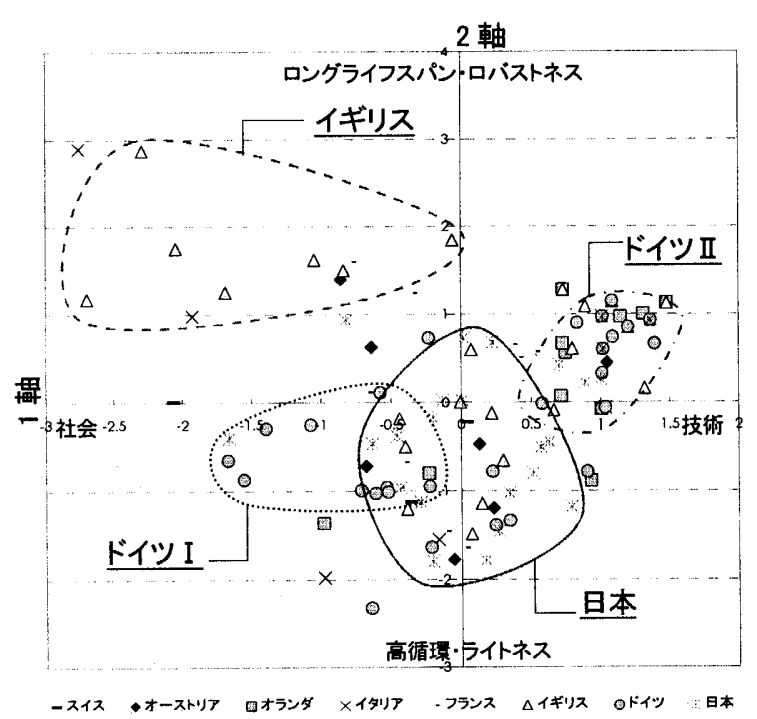

図 9 1-2 軸 2 次元グラフ(地域別)
一方、2 軸方向には広く分布する傾向にあり、集合住宅において は、ロングライフスパン・ロバストネスの傾向を持つサステナブ ル建築と高循環・ライトネスの傾向を持つサステナブル建築との 双方があることが分かった。また、事務所建築のグループでは、 その多くが第 1 象限に分布しており、高層化、高効率の設備機器 の採用などにより、技術依存度が高いことを高いことを裏付ける 結果となった。美術館・学校などの公共施設においては、全体的 に分散化する傾向にあり比較的特徵が弱いことが明らかになった。 これは、近年、公共施設の多くが、複合化・多様化する傾向にあ ることを示していると考えられる。

\section{2. 規模別分析}

事例を規模別に散布図として示した結果を図 8 に示す。規模別 にサステナブル建築の特性を分析すると、「Small」、「Medium」 の比較的規模の小さいグループは、第 2 象限から第 3 象限にかけ て多く分布するのに対し、「X Large」、「Large」の比較的規模の 大きいグループでは、第 4 象限から第 1 象限にかけて多く分布す ることが明らかになった。この結果より、規模の小さいものから 規模が大きくなるに従って、技術依存度が高くなる特性が明らか になった。また、同様に、規模が大きくなるにつれてロングライ フスパン・ロバストネスの傾向が強くなることが明らかになった。 これは、大規模建築ほど、学校やホールなど公共性の高い建築が 多く、建物の耐久性が求められた結果であると考えられる。

\section{3. 地域別分析}

事例を地域別に散布図として示した結果を図 9 に示す。地域別 にサステナブル建築の特性を分析すると、第 2 象限にイギリスの グループが分布し、イギリスのサステナブル建築においては、社 会との関係性が強く、かつロングライフスパン・ロバストネスの 傾向があることが明らかになった。また、ドイツのグループでは、 主に第 3 象限に分布し、技術依存度が低く高循環型の傾向がある 「ドイツI」と、主に第 1 象限に分布し、技術依存度が高く、ロ ングライフスパンの傾向が強い「ドイツII」の 2 つの傾向が明ら かになった。これは、ドイツの現代建築におけるデザイン特性 (ロ 一テク・低負荷の「バウビオロギー」＝「ドイツI」、ハイテク・ 高効率の「ハイテックスタイル」＝「ドイッ【」）と合致する結果 となった。一方、日本のグループにおいては、第 3 象限から第 4 象限にかけて広く分布する傾向にあることが明らかになった。全 体として中庸であるが、高循環型の傾向が現れており、「スクラッ プ・アンド・ビルド」に象徵される日本における建築産業の傾向を 読み取れるのではないかと考えられる。

\section{5. まとめと今後の課題}

本研究では、延べ 650 事例のサステナブル建築を収集し、欧州 及び、日本における 135 の事例を抽出した。135の事例とJIAに よる 32 項目の分類を元に、SD 手法を 17 項目の分類に再構成し た。また、その SD 手法について、数量化 3 類による多変量解析 を行い、項目ごとの負荷量を明らかにした。次に、その結果をグ ラフ化し、サステナブル建築の特性を考察した。その結果、サス テナブル建築に用いられるS D手法には「社会 $\Leftrightarrow$ 技術」、「高循 環・ライトネス $\Leftrightarrow$ ロングライフスパン・ロバストネス」、「歷史・ 風土 $\Leftrightarrow$ 経済」という、3つの特徴的な軸性による対照的なべク 
トルがあることが明らかになった。また、代表的な 8 つサステ ナブル建築の事例をそれぞれの特徵軸空間上に散布して示すこと

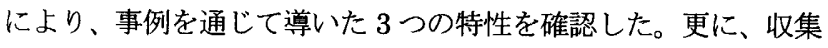
した事例を用途別・規模別・地域別に分類した上で、それらを同 じ 1-2 成分軸上に散布して示し、そこから、用途別、規模別、 地域別のサステナブル建築のデザイン特性について明らかにした。

以上より、サステナブル建築については、いくつかの SD 手法 が相互に組み合わされることで、建築を持続可能にしていること が明らかになった。また、SD 手法の組み合わせ方によって、そ れぞれ特徵的な建築事例となっていることが明らかになった。更 に、その傾向を用途別、規模別、地域别に明らかにした。こうし た関係性は、経験的には知られているものであるが、今回の SD 手法の分析によって、サステナブル建築のデザイン特性を明確に した。

本研究では、欧州及び日本のサステナブル建築の事例を通じて $\mathrm{SD}$ 手法の分析を行いその特性を明らかにした。今後は、アジア 諸国、米国などの事例を対象とするほか、戸建住宅等についても 対象とすることで幅広く地球規模での事例収集・分析を行い、少 ステナブル建築のデザイン特性の詳細な分析と体系化を試みたい。

\section{注釈}

注 1 ) ライトネス(Lightness)

「高循環・ライトネス小「ロングライフスパン・ロバストネス」の表現は、いずれ も建筑の物理的な寿命だけでなく、社会的な寿命に関する密葉として用いた。「イイト ネス」は、面訳すれば「軽いこと、怪さ、軽微さ」の意味であるが、本稿では物理的

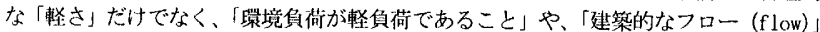
の意味で用いた。

\section{注2）ロバストネス(Robustness)}

「ロバストネス」は、直訳すれば、「強勒性、耐久性、耐力」の意味であるが、本稿 では物理的な「耐久性」だけでなく、「建築的なストック (stock)」の意味で用いた。 ここで、「耐久性」について、物理的な酎性を示す「デュラブル (durable)」ではなく、 (経済などの)健全性や強勒性を示す「ロバストネス(robustness)」を用いた理由は、 巣に物理的な酎性(物理的な寿命)を京すだけでは、サステナブル建築とは成りえない という村上・白石諭文の趣旨を尊重したことによる。

\section{参考文献}

1) Our Common Future : WCED; World Commission on Environment and Development, Oxford University Press, 1987

2) Declaration of Interdependence for a Sustainable Future, UIA / AIA World Congress of Architects Chicago, 1993.6

3) OECD2001 : Sustainable Development Critical Issues, OECD, 2001

4）村长三編著, 村上周三,和泉洋人,野城智也,安藤尚一,長谷川貴彦: サステイナ ブル建筑と政策デザイン，慶應義塾大学出版会,2002

5) OECD2003: Environmentally Sustainable Buildings Challenges and Policies, OECD, 2003

6）新日本建築家協会編：サステナブル・デザインガイド- 生き続ける建貿のデザ イン, 彰国社, 1995

7） サステナナブル・ビルディング普及のための提音：日本建築学会地球環境委筫会 サスデナブル・ビルディング小委員会,1999

8）村上周三,白石靖幸：建築における持続可能性について，日本建築学会大会学術 講演梗概集 D-1,P853-854,1998.9

9）新建築 : 建築 20 世紀 PART1,PART2, 新建築社:1991

10）エミリオ・アンバース: グリーン・オーバー・ザ・グレー, 建築文化,57·90,1995

11) Thomas Herzog : Solar Energy in Architecture and Urban Planning, Prestel Verlag, 1996

12） $\mathrm{a}+\mathrm{u}$ : 特集サスティフブル・アーキテクチュア サスティナブル・エンヴァイロ メント,『a+u』9705, a+u Publishing, 1997

13) Peter Murray and Mary Anne Stevens : New Urban Environments, The Royal Academy of Arts, London and Prestel-Verlag, 1998

14) Ed Melet : Sustainable Architecture, NAI Publishers, 1999

15) Miguel Ruano: Eco Urbanism, Editorial Gustavo Gili,1999

16） キャサリン・スレッサー著, 難波和彦監訳:エコテック 21 世紀の建築, 鹿島出 版会, 1999

17）鹿岛汁版会：環境共生の現在，『SD』9901，1999

18）日経 BP 社: 「欧州に学ぶ建築転生術」『日経アーキテクチャー，12-13』, $\mathrm{p} 32-\mathrm{p} 83,1999$

19） 日経 $\mathrm{BP}$ 社 : 「エコデザイン」，『日経アーキテクチャー，3-6』、p37·p73,2000

20）日経 BP 社：「環境デザイン 2000 」『日経アーキテクチャー、1225』、 p24-p54,2000

21）日経 BP 社: 「環境時代のグローカルデザイン」，『日経アーキテクチャー, 6-25』, p60-p87,2001

22）日程 BP社:「今こそ建物緑化」、『日経アーキテクチャー, 10-29』, p52-p83,2001

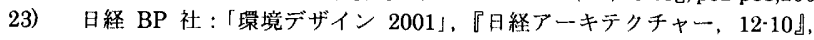
p8-p40,2001

24）日経 BP 社：「ガスタンクを複合施設に」、『日経アーキテクチャー，2・18』、 p19-p21,2002

25）日経 BP 社：「環境包囲網を突破せよ」，『日経アーキテクチャー，5-27』， p54-p77,2002

26）日経 BP 社：「強大な日陰をつくる発電ルーバー」『日経アーキテクチャー, 7-22』, p8·p13,2002

27）日経 BP 社:「自然力を高める」、『日経アーキテクチャー, 10-14』, p50-p82,2002

28）日経 BP 社：「環境デザイン 2002」、『日経アーキテクチャー, 11・11』, p52-p85,2002

29) Architectural Design : Green Architecture, Architectural , Vol71/No.4 July John Wiley \& Sons Ltd.,2001

30) Dominique Gauzin-Muller : Sustainable architecture and urbanism, Birk hauser,2002

31) Solar Architecture : DETAIL, 2002.06, DETAIL,2002

32）日本建築学会:『地球環境建築のフロンティア』0302,日本建築学全,2003

33）エコロジーと建築: 『建築雑誌』Vol.99, 日本建築学:会, 1984

34）川村健一，小門裕幸：サステイナブル・コミュニティ，学:芸出版社 1995

35) Sophia and Stefan Behling : Sol Power, Prestel Verlag, 1996

36) Richard Rogers and Phillip Gumuchidjian : Cities for a Small Planet, Faber and Faber Limited, 1997

37） Glass \& Architecture1998 春:「エコロジーとテクノロジー」『Glass \& Ar chitecture』，旭硝子株式会社, 1998

38） Glass \& Architecture 1998 夏:「ジャパン・エュロジカル・アーキテクチュア」, 『Glass \& Architecture』, 旭硝子株式会社, 1998

39) Hildebrand Frey : Designing the city, E\&FN Spon, 1999

40) Richard Rogers and Anne Power : Cities for a small country, Faber and Faber Limite, 2000

41) Brian Edwards , David Turrent: Sustainable Housing,E\&FN Spon,2000

42) Earth Pledge Foundation Edit : Sustainable Architecture White Papers, Earth Pledge Foundation, 2000

43) Peter Hall and Ulich Pfeiffer : Urban Future 21, E\&FN Spon.2000

44）岩村和夫監修，日本建築家協会，ビオシティ編:サステイナブル建築最前線,ビオ シティ,2000

45) Mike Jenks and Rod Burgess : Compact Cities, Spon Press,2000

46) Gert de Roo and Donald Miller : Compact Cities and Sustainable Urban Development, Ashgate Publishing,2000

47) Katie Williams, Elizabeth Burton and Mike Jenks : Achieving Sustainable Urban Form, E\&FN Spon, 2000

48) Antonia Layard, Simin Davoudi and Susan Batty : Planning for a Sustainable Future, Spon Press,2001

49) Guy Battle, Christopher McCarthy : Sustainable Ecosystems, Wiley-Academy,2001

50) Glass \& Architecture 2002 夏:「コンバージョン」,『Glass \& Architecture』, 旭硝子株式会社, 2002

51）日本建築学会編：地球環境建築のす寸一め, 彰国社,2002

52). Arian Mostaedi, Carles Broto, Josep Ma Minguet : Sustainable Architecture low tech houses, Gingko Press, 2002

53) Arian Mostaedi, Carles Broto, Josep Ma Minguet: Sustainable Architecture high tech housing, Gingko Press, 2003

54) Ed van HInte, Marc Neelen, Jacques Vink, Piet Vollaard : Smart Architec ture,010Publishers,2003

55) Marc Emery, Luciana Ravanel : Innovation Durables Appropriate Sustainabilities , Birkhauser,2003

56) Randall Thomas : Sustainable Urban Design, Spon Press,2003

57) Terry Williamson, Antony Radford, Helen Bennetts : Understanding Sus tainable Architecture, Spon Press,2003

58）資源循環型住宅技術開発プロジェクト編著，清家剛・秋元孝之監修：サステイ ナブルハウジング，東洋経済新報社, 2003

59) Raymond J. Cole : ‘Assessing the Shift from Green to Sustainable 」, 『都iti . 建築のサステナブル・デザイン』/「未来都市の生:態恒常性【学」国際ワークシ ヨップ, 豊橋技術科学大学, 2003

60) Glass \& Architecture 2003 春：「サステナブル・アーキテクチュアの射程」 『Glass \& Architecture』, 旭硝子株式会社,2003

延べ 650 件のサステナナブル建築の事例は、9）から60）までの文献より収集した。

\section{謝辞}

本研究は、慶應義塾大学 21 世紀 COE プログラム「知能化から生命化へのシステムデ ザイン」の助成を受けて行ったものである。この場を借りて、お礼申し上げる。 